\title{
The Study on Music Appreciation Teaching from the Perspective of Multiculturalism
}

\author{
Jianjun Liu \\ Music Department, Gannan Normal University, Ganzhou 341000, China \\ liujianjun@126.com
}

Keywords: music studying, appreciation teaching, multicultural perspective

\begin{abstract}
Music appreciation teaching plays an active role in promoting students' aesthetic level of music, improving students' humanistic quality and promoting the improvement of students' comprehensive quality. With the progress of the times, the development of the economy and the frequent cultural exchange, the concept of multicultural music culture has become an important guiding principle in the music appreciation teaching. Therefore, from the multicultural perspective, teachers should correctly handle the relationship between inheritance and innovation, selection and acceptance, and promote the smooth development of music appreciation teaching. There are usually two kinds of auditory classifications: external hearing and internal hearing. External hearing means that people can hear the sound of others, and the inner hearing is the way people can imagine what the music should have. Although both of them belong to music appreciation, they are actually two different concepts. The former is inherent in human beings, while the latter must be purposefully trained, which is the content of music appreciation teaching. The ability of music appreciation plays a very important role in understanding music art. Music appreciation course includes a very wide range of contents. However, the improvement of this course needs to have a solid and good grasp of related knowledge.
\end{abstract}

\section{Introduction}

Music appreciation discipline actually includes a very rich curriculum content, because its content will be influenced by specific social, political, economic and cultural factors, so it can show the development level of a social music. Music appreciation includes many other content, for example for an understanding of music history, or music genre classification and characteristics, and to understand the lives of the music concept and some music marked by artists and their creative works, but also to learn the music aesthetics and music learning basic knowledge the. If we want to perform excellent and effective music appreciation, we need to know clearly the background and specific connotation of music in that era, and understand the related functions of music. That's the real effective way. Nowadays, multicultural exchanges have become increasingly frequent, this also provides for the teaching of music appreciation is a good cultural atmosphere environment, in this context of learning music should pay more attention to the cultural connotation of the control, as a result, multicultural and music appreciation teaching has become a mutual benefit the multicultural music appreciation teaching is the very profound cultural support.

\section{The Background of Multicultural Education}

In the middle of the twentieth Century, there was a general appearance in the world from unit society to multiple society. For many countries constituted by unit nationalities, such as Canada, the United States and Australia, the impact of multi ethnic groups and their cultural invasion on the original unit society is huge. In order to solve the conflict and opposition of multiculturalism to the unit culture and society, scholars have put forward a variety of different solutions. Therefore, the trend of multiculturalism began to rise, and the reason for its rise is to solve the misunderstanding and conflict between different ethnic groups in different ethnic groups. Take Canada as an example, 
in 1988, Canada promulgated the multiculturalism act, which illustrated the multiculturalism as the foundation for building a country. It showed Canada's emphasis on multiculturalism. The world was pluralistic, especially after the Second World War. The progress of science and technology makes people all over the world have more opportunities to contact and communicate, and promote the emergence of the immigrant atmosphere. Some units of national acceptance due to a large number of war refugees and change original social structure, some minority is because a large number of overseas to learn some technical personnel, because in foreign bride:: the reasons for all countries in the world gradually to a multicultural society. As a result, many countries have begun to attach importance to the topic of multiculturalism and hope to solve their derived social problems in various ways. Education is considered to be the best way to culture continuity. The topic of multiculturalism began to be mentioned frequently in various educational conferences or academic seminars. Therefore, educational scholars began to seek the definition of multicultural education from multiculturalism, and the concept of multicultural education and its implementation methods and importance in schools. At the time of exploring the implementation of multicultural education to the school curriculum, scholars have put forward different methods or suggestions.

\section{The Way of Music Education in China}

Since the "54" movement, China's music industry not only systematically accepted the theory and interpretation of western music, and put it as the center of the entire contents of music education, the primary school music class from now to university music education professional music specialty courses are in the West music system as the leading, and to Chinese to transform traditional music, western music and the spirit Chinese model has become a consensus in the music concept, formed in the western music thinking based thinking mode. In music teaching, we only pay attention to learning foreign traditional music, do not attach importance to the national music tradition, and learn from foreign music is also limited to European music. The learning of European music mainly learns the 17 19 century professional creation music of several Western European countries. Due to not fully include eclectic native music culture, music culture of human achievements, content with staying where one is seriously affected the development of our country, higher education of music and national music education. For example, we often find this phenomenon in practice teaching. It is found that many of our Uygur students sing their national songs before entering school, though they have not received the training of professional music schools one day. But the strange thing is that after several years of professional learning from the western bel canto, down, bel canto singing very not good, the national thing also lost. In fact, the student is accepted in the school of western music and he accepted his to the music of the mode of collision, always want to learn music with western law to explain its folk music is of course a lot can not be explained through this phenomenon, they also make each one of our educators we feel the failure of education. In the final analysis, the lack of multicultural music education in music education is the result of the idea.

\section{The Basic Concept of Multiculturalism}

The concept of multiculturalism originated in the US in the 80s, because the United States is a very typical immigrant country, so American culture has always had a very strong inclusiveness and openness. While the United States has the characteristics of members of society is extremely rich, every class of people will pursue great freedom in this society, however, after a series of historical changes, the United States has formed a multicultural society has different ideas in culture in harmony. Many scholars believe that culture is a common role in mental and physical activities, with a spirit of product process, create not only so, culture should also include specific psychological and behavior can be formed on the creation process of spiritual products in. This is the origin of cultural forms should be diversified, according to different national cultural characteristics of the construction of a different ethnic cultural characteristics between the two cultures is not high and low quality of the points, between each culture should be harmonious and 
mutual equality and coexistence, in the development process of the whole society should also show respect for the same different ethnic culture and identity. Multiculturalism should be said to be a product of a particular era, which is closely linked to the great changes that have occurred in a society under a particular era. Moreover, this multiculturalism is undoubtedly positive and progressive. The emergence and generation of this theory itself means the progress of the society itself, showing the success of multi-ethnic cultural integration.

\section{The Relationship between Multiculturalism and Music}

From the perspective of multiculturalism, studying music not only enriches the single form of music creation carrier, but also reveals the strong tolerance of multiculturalism to a great extent. Moreover, when appreciating music, we should not only simply analyze and appreciate the music works, but also integrate every musical work into the multicultural connotation background. Then we will grasp the whole content and analyze it later. Only when music works are integrated into cultural content, can the two combine to make them all full of vitality, and only when music works are put into multiculturalism, can they be full of vitality of new blood. From the perspective of multiculturalism, music has become an important part of culture. Both of them need to achieve real communication and integration in more and more fields. Because pluralistic music has played a good role in promoting and promoting the formation of multiculturalism, while music has got better development space and solid foundation under the influence of multicultural background. When music meets the culture, it can be said to complement each other. Culture is the foundation of the development of music and the bridge of communication. In some sense, if the culture lost music, it is with defects, not complete; if the lost music culture, music will become blank, no vitality. And, under the multicultural background, to emphasize more aesthetic value of music, along with the development of social progress, the music hadn't been too popular in the areas of concern but more development is out of the world of its own strong, which leads to the traditional music theory and aesthetic point of view will be great change. In today's era, we must fully understand and understand the connotation of multicultural era, so that we can perform effective music appreciation and evaluation more effectively. The music idea produced in multiculturalism is very conducive to the improvement of music appreciation and taste ability. The teaching of music appreciation is a focus on music exchange and inheritance activities, under the influence of multicultural values concept, music appreciation has become the target of training music fans or critics will own views of human feelings to a world view, in this view, let them learn more cherish their own national culture, classical music content, and then make the music get better promotion and development.

Today, multicultural communication is becoming more and more frequent, so there is no single tradition in the way of music development, and it should set up a world vision. But when we understand multiculturalism, we need to set up a national culture understanding point of view, because national culture is able to establish a solid foundation for the sound development of music. Every nation has different music history of their own culture, so any kind of music form will be Chengdu national culture view, belief, consciousness and thinking, these contents have become ingrained in the form of folk music, hidden in the depths. Therefore, the ethnic music is music can develop more focus on the national cultural heritage and development, especially in full of multicultural development today, only fully maintained every kind of music unique national character, to ensure the national music inheritance, rather than being replaced by foreign the music culture. Only when music culture is established on the basis of multicultural culture and national culture can we make it more targeted in music appreciation teaching. There are several kinds of music appreciation: the national music, the western music, and the national music of other countries outside the West. But it is not limited to the above kinds of music appreciation, because there will be many new music forms when multicultural communication is injected into music. The birth of multiculturalism and music appreciation is not conflicting with each other. They are mutually beneficial and win each other, and they all inject fresh vitality into each other. 


\section{The Difference between the Music Appreciation}

Under the multicultural music appreciation mainly emphasizes is music appreciation down in a multicultural perspective, mainly focus on the culture of music or speech culture can express the artistic feelings, and in the process of music appreciation, appreciation of the need to pay attention to enhance personal qualities as well as to enhance its knowledge content. Multicultural music appreciation is in a very open mind, show a very lively and vivid form of music performance in the form of appreciation can be with the music creator or artist to produce resonance, spiritual communication. Moreover, multicultural music appreciation is equivalent to a music appreciation based on multicultural background. It fully attached importance to a worldwide view of music culture, and paid more attention to the continuation and development of local music. Under the multicultural background, music appreciation is more fully manifested its own practical experience, so that appreciators can really feel their music creators' real life experience at that time.

The subjective idea of multiculturalism is to emphasize the equality and openness of the world, so we should take this as the center for music appreciation teaching and see its music content from a more comprehensive perspective. Music Appreciation under the background of multi pays special attention to the music content into the overall atmosphere of culture, such music appreciation in the appreciation of those who will be able to be the perfect combination of humanistic spirit and cultural connotation of the music and its original music works this way, then the appreciation and thinking of music works as the music itself, it will add more vitality. The traditional music appreciation concept and modern music appreciation concept of contrast, so it is very misfits, and in the diversified today, if only conservative, always maintain a traditional culture, does not pay attention to the new spatial diversity, music appreciation space is not the benign development of the future.

\section{How to Promote and Develop Music Appreciation Teaching Better}

We should learn to deal with the relationship between music appreciation and the diversity of diverse cultures under the premise of multiple musical perspectives. Music appreciation is a process that appreciators enjoy the enjoyment of beauty from the appreciation of the designated works. The spiritual pleasure can not be given and compared by the material. Multi culture makes music appreciation has been a new breakthrough era, so we must learn to think more rational when it comes to music appreciation, pay attention to the connotation and the breadth and depth, and make the full use of modern information technology in the role of music appreciation. To collect the relevant data using the Internet music appreciation, or the use of Internet has become a way of information dissemination and so on, music appreciation researchers can also take advantage of the Internet as a platform for music in the above discussion and exchange, collision and friction only thought to making music appreciation to get fresh blood more vibrant. In a word, the diversity of music appreciation can promote the development of music appreciation to a higher level of development. Generally speaking, music should not be a closed, self-sufficient art class. If it keeps deviating from the social process, and keeps the traditional idea and does not blend in with its new school, it will never have much room for improvement and development. In a multicultural society occupy an important position today, music appreciation link should be on the basis of establishing new view right, take a more excellent appreciation of scientific and reasonable methods, combined with the basic characteristics of music appreciation of their own, in order to promote the development of music appreciation to the real road.

\section{Acknowledgements}

"Research on standardized management of the Music Training Institute-With the Zhanggong district, Ganzhou City as an example” College project of humanities and social sciences in Jiangxi province, 2016 (Grant NO. JC162052). 


\section{References}

[1] R.D.L. A study of the teaching practice of music appreciation from the perspective of multiculturalism [D]. Sichuan Normal University, 2012.

[2] L.L. The music appreciation [J]. writer from the multicultural perspective, 2013 (24): 238-239.

[3] Y.F.F. The study of aesthetic education in the teaching of music appreciation in high school [D]. Shaanxi Normal University, 2011.

[4] J.L. The current situation and Countermeasures of music appreciation teaching in ordinary high school [D]. Shandong Normal University, 2011.

[5] K.Z. Kumiko middle school music appreciation teaching. [D]. research on the problems and Countermeasures of Liaoning Normal University, 2010.

[6] W.D. Research on the initiative of the aesthetic subject in the teaching of music appreciation [D]. Hunan Normal University, 2009.

[7] X.J.Z. Research on the teaching of high school music appreciation [D]. Nanjing Normal University, 2011.

[8] Z.J.S. The development of College Music Appreciation Teaching in China of [J]. Journal of Hotan Teachers College, 2011 (5): 111-114.

[9] T.Q. The rational and aesthetic analysis of college music appreciation teaching [J]. Journal of Nanjing Institute of Technology: Social Science Edition, 2005 (2): 51-54.

[10] J.Z.Z. Research on the teaching method of music appreciation course [J]. Journal of Xi'an Polytechnic University, 2010 (5): 691-694700. 